\title{
Financialization at the international level: evidence from emerging market economies *
}

\author{
Raquel A. Ramos **
}

\begin{abstract}
The paper focuses on the manifestations of financialization in the international sphere, which it defines as the increasing magnitude of finance and its decoupling from earlier functions and logic as the speculative motive is strengthened. With financialization the motive of finance is no longer to finance trade and production but to accumulate wealth, which in emerging market economies (EMEs) takes place through innovative products and practices that have in common the focus on exchange rate returns, resulting in a strengthened speculative motive. The article reviews the financialization literature highlighting how the different closed-economy aspects impact the international sphere. It conducts empirical analyses based on the financial integration of a country and on the characteristics of its currencies' FX markets to assess the presence of financialization and its characteristics among EMEs, indicating certain countries where this process is more intense.
\end{abstract}

Keywords: Financialization; International economics; Emerging market economies; Financial integration; FX markets.

\section{Resumo}

\section{Financeirização no nível internacional: teoria e evidência empírica para economias emergentes}

$\mathrm{O}$ artigo trata das manifestações da financeirização no âmbito internacional, que é definida como a crescente dimensão das finanças e a sua desvinculação de suas antigas funções e lógica à medida que o motivo especulativo se intensifica. Com a financeirização, o motivo das finanças não mais está ligado ao financiamento da produção e do comércio internacional, mas à acumulação de riqueza, o que, em economias emergentes (EMEs) é feito através de produtos e práticas inovadores, que têm em comum o foco em ganhos com variações cambiais, resultando em um motivo especulativo intensificado. $\mathrm{O}$ artigo discute a literatura sobre a financeirização, chamando atenção para como diferentes aspectos de uma economia fechada impactam a esfera internacional. Ele conduz análises empíricas baseadas na integração financeira e nas características dos mercados de câmbio de cada país para avaliar se há presença de financeirização entre as economias emergentes, apontando para um processo mais intenso em algumas delas.

Palavras-chave: Financeirização; Economia internacional; Economias emergentes; Integração financeira; Mercados cambiais.

JEL F41, F310, B50.

* Article received on April 10, 2017 and approved on September 18, 2017.

** Associate Researcher at the Centre d'Économie de Paris Nord (CEPN), Paris, França. E-mail: raquelalmeidaramos@yahoo.com.br. 


\section{Introduction}

A rising number of studies are dedicated to the changes that have been shaping the current phase of capitalism, from increasing shareholder orientation to the major increase in FX transactions. The developments that characterize financialization are numerous, and the fact that they are often individually referred to as financialization might make it an elusive concept. Financialization definitions have however a common point: they are related to the rising importance of finance - which made Epstein's (2005) broad definition a recurring one: "financialization means the increasing role of financial motives, financial markets, financial actors and financial institutions in the operation of the domestic and international economies" (p. 3). This article's analysis of financialization is based on a broad understanding of the term that derives from the current literature on financialization, the studies carried out by Minsky (1986) on "Money Manager capitalism"1 and those carried out by the French Regulation school': as Boyer's (2000) "Finance-led growth regime", Chesnais' (2001) "Financialized growth regime", and Plihon's (2003) "Shareholder capitalism".

As will be seen throughout the article, the literature is largely focused on aspects of the domestic-economy, with the manifestations of international financialization being mostly only superficially treated, what can yield confusion between concepts such as financialization and financial globalization. In addition, these phenomena are mostly studied with regards to advanced economies ${ }^{3}-$ and indeed these are the ones who presented the conditions favoring the liquidity creation and the rise of money managers. This article aims to bridge these two gaps in the literature: it suggests a definition of financialization at the international level and presents empirical evidence of its presence among emerging countries.

In addition to this introduction, the article is divided in three sections: section 2 discusses the different phenomena that have been referred to as financialization; section 3 presents the empirical evidence; section 4 concludes and discusses the implications of the findings.

(1) Minsky argued that capitalism has gone through four stages in the US: Commercial, Finance, Managerial, and Money manager capitalism - that are mostly understood as consecutive, the last one representing the current period, but can also coexist in an advanced capitalist economy (Minsky (1986); Minsky (1990); Minsky (1992)).

(2) According to the French Regulation school, different regulation modes are observed inside the capitalist system (that is a production mode) based on the different combination of: the monetary constraints (financial and monetary policies); the wage-setting rules; the industries' organization; the form of integration of the economy to the international regime; and its governmental form (Boyer, 2004). The current regulation mode found in advanced countries is financial ("Capitalisme Financier"). It has succeeded Fordism, that ruled from the 1950s to the 1970s and was marked by higher stability. Also see Chavance et al. (2007) and Amable (2005).

(3) See Bonizzi (2013b) for a review of critical approaches to finance in the context of developing economies. For the specific case of the Brazilian economy, see Paulani et al. (2009) and Bruno et al. (2011). 


\subsection{Methodological notes}

Three main sets of data are used in the empirical analyses presented in section 3, about financial integration, foreign exchange (FX) markets, and productive-economy related indicators. Data on financialized integration is taken from IMF's International Investment Position. Financial integration refers to the value of liabilities owned to foreigners plus assets held abroad, deducted for reserves. This exclusion was done to differentiate public and private decisions and given the large amount of reserves among EMEs.

FX market data are based on the Bank of International Settlement's (BIS) Triennial Surveys of FX Markets. The changes in the structure of FX markets are analyzed by comparing the results from the last five surveys: 2004, 2007, 2010, 2013 and 2016. Changes from one survey to the other are presented in line graphs for ease of reading, but no data for "missing" years were included. The surveys refer to the average daily transactions of the month of April of the respective year ${ }^{4}$. The year of 2004 was chosen for being next to the beginning of the current cycle of capital flows to EMEs, 2003 (Prates, 2015). Moreover, the prior survey, conducted in 2001, could have been potentially biased due to the currency crises in EMEs and was conducted for a much smaller amount of currencies from EMEs (hereafter emerging currencies; 11 , instead of 20 in 2004). Note that the analyses are carried out for selected currencies for which data are available in both the 2004 and the 2016 surveys (presented below), which does not cover all of the currencies studied in the 2004 or 2016 surveys.

The third set of data includes indicators about the countries' GDP and foreign trade, which are taken from the World Bank's World Development Indicators (World Bank, 2016). For most indicators, the latest data available in this database is 2015. These are the ones used to build "2016" indicators with BIS 2016 data. One exception is New Zealand, whose trade data is for 2014. The WB has no data for Taiwan.

EMEs are defined as the developing countries that are most integrated into the international financial system. In line with Chesnais (1997), who points out that financial globalization is defined by the decisions of portfolio managers, the article proposes a 'financial-markets oriented' operational definition for EMEs. Specifically, it uses the countries who are part of the MSCI index as a benchmark, a broadly used indicator of financial returns in EMEs. As the list of countries in this index changes over time (which is in line with the theoretical definition of EMEs)

(4) The use of a month as a representative of the year has an important drawback in financial market data given their fickle nature. For instance, the BIS (2016) states that the fall of activity from April 2013 to April 2016 might be due to a hike of activity in 2013 due to changes in the monetary stance in Japan. This is however the best data available on FX markets on a global scale. 
and with the aim of having a more structural picture of EMEs, recently-added countries such as Egypt and Qatar were not included. Greece was also not considered given the different issues it faces as a Euro Area country. The final list of EMEs includes 20 countries, their respective currencies being: the Argentinean peso (ARS), the Brazilian real (BRL), the Chilean peso (CLP), the Chinese yuan (CNY), the Colombian peso (COP), the Czech Koruna (CZK), the Hungarian forint (HUF), the Indian rupee (INR), the Indonesian rupiah (IDR), the Korean won (KRW), the Malaysian ringgit (MYR), the Mexican peso (MXN), the Peruvian nuevo sol (PEN), the Polish zloty (PLN), the Russian ruble (RUB), the Thai baht (THB), the Turkish lira (TRY), the New Taiwanese dollar (TWD), and the South African rand (ZAR).

The analyses consider 11 currencies from advanced economies: the Australian dollar (AUD), the Canadian dollar (CAD), the Swiss franc (CHF), the Danish krone (DKK), the euro (EUR), the Pound sterling (GBP), the Japanese yen (JPY), the Norwegian krone (NOK), the New Zealand dollar (NZD), the Swedish krona (SEK), and the United States (US) dollar (USD).

\section{The three main phenomena of financialization}

Studies on financialization cover a large range of changes seen in capitalism. Although not directly associated with finance at the international level, these should be discussed for having an impact on it. To facilitate this task, the article suggests grouping the different phenomena into three main sets:

i) the changing relationship between finance and other economic sectors, with the increasing importance of the first and its associated class group, the rentiers;

ii) the changes within the financial system, with the increasing importance of markets, the evolution of banks, and the sophistication of finance through innovations of products and practices; and

iii) the increasing magnitude of finance at the international level with the decoupling from its earlier functions and logic.

The article is focused on the third phenomena, which is certainly the least studied of the three. As will be seen, although some of the analyses of financialization mention some qualitative changes related to finance at the international level, most economic studies in this sphere are quantitative, and limited to the aspect of financial integration. The study of finance at the international level from the background of financialization however adds to our understanding of international economics in order to demonstrate that financial integration has not only changed in magnitude, but also in its function and dynamics. The analysis of the third phenomena, and the derived suggestion of a definition of financialization at the international level, must therefore be carried out from the broader picture of 
the ample changes of capitalism. Accordingly, this paper discusses the two first phenomena before analyzing the third. The second will be more extensively analyzed given its direct and strong implications on the third.

\subsection{The changing relationship between finance and other economic sectors}

A first and broadly studied aspect of financialization is the evolving association between finance and other domestic sectors. It has different nuances, such as the placement of capital or profit-making in the financial rather than the production sphere, the focus on shareholder value, and the rise of rentiers.

The evolution of profit-making forms is the focus of Lapavitsas (2009) and Krippner (2005, p. 173), the latter defining financialization as a "pattern of accumulation in which profit making occurs increasingly through financial channels rather than through trade and commodity production". Epstein and Power (2003) highlight the increasing importance of profits from financial transactions in nonfinancial companies and Stockhammer (2004, p. 719) defines financialization as "the increased activity of non-financial businesses on financial markets", measuring it by the corresponding income streams. Another element of this phenomenon is the weight of financial assets vis-a-vis tangible assets (Orhangazi, 2008).

A different manifestation of the evolving relationship between finance and the other sectors of the economy is the increasing focus on shareholder value inside companies. An important part of the recent research on financialization studies this issue and Stockhammer (2004) even sees the study of corporate governance and labor relations as the first area of debate around financialization. The rising focus on shareholder value led to the adoption of sophisticated techniques of financial engineering and the following practices: i) the broad use of mergers and acquisitions; ii) a greater focus on their core activities; iii) the re-engineering of production chains; and iv) downsizing through stock buyback. The increasing focus on shareholder value cannot be dissociated from the increasing use of equities as a form of funding at the expense of banking financing (Plihon, 2003).

The main point of the literature is to identify whether the focus on shareholders' interests and the consequent distribution of profits takes place at the expense of reinvestment, which would be detrimental to growth ${ }^{5}$. This development is known in the literature as a change in management strategies from "retaining and investing" profits to "downsizing and distributing" them (Lazonick and O'Sullivan, 2000). Indeed, this short-termism of management would have decreased managements' animal spirits with respect to real investment, and caused the draining of internal means of finance for allowing higher dividend payments and share

(5) For examples of the working of "financialized" firms and the potential consequences of growth on a Stock Flow Consistent framework, see Reyes and Mazier (2014) and Do Nascimento and Macedo e Silva (2016). 
buybacks in order to boost stock prices and shareholder value - with negative effects on growth (Hein, 2011). Minsky observed the rise of short-term thinking of companies in the 1990s. In his words, with these changes, the capital development of the economy had "taken a back seat to the quest for short-run total returns" (Minsky, 1990, p. 34-35). Empirical studies found evidence of the negative consequences brought about by this change: financialization would have contributed to the slowdown in accumulation of capital goods since the Golden Age in France, the USA and the UK (but not in Germany), as management adopted the preferences of rentiers (Stockhammer, 2004) - the "wealthy people who get most of their incomes from owning financial assets, rather than working or from owning productive assets" (Epstein; Power, 2003, p. 229).

Although the main focus of the literature is on reinvestment and capital accumulation, financialization could also have negative impacts on growth through a decreased potential to innovate and by worsening distribution. Minsky (1990) calls attention to the former: as liabilities' structures pledge a major part of cash flows, venture capital might be enough for funding smaller innovative efforts, but not the financial investment required by capital needs of advanced technology. Regarding the effects on distribution, Epstein and Power (2003) argue that the increase of rentiers' share of national income has not occurred without losses of non-financial institutions and that this increase has happened at the expense of the labor's share. Boyer (2000) argues that if the profits from the rentiers were redistributed, a boom in stock markets and in consumption could occur.

Financialization is thus closely related to the rise of rentiers, which cannot be dissociated from other aspects of financialization. Rentiers have especially benefited from the prioritization of paying shareholders and from the financial innovations of products and practices that increased profit possibilities. In a clear spiral, these two features are however also a consequence of the rentiers' increasing power: with increased economic power, rentiers gained political power, that enabled them to push for policies they have greatly benefited from, increasing their power even more (Epstein; Power (2003); Lapavitsas (2009); Palley (2007)).

Perhaps rentiers' interconnectedness with the other aspects of financialization is what has made them so unambiguously significant in the financialization literature. Epstein and Power (2003) and Stockhammer (2004) use rentiers' remuneration as indicators of financialization. The definition of financial globalization proposed by Chesnais (1997) places an important focus on rentiers: financial globalization is a new age ruled by a financial capital of "rentier character". The increasing remuneration of rentiers is one of three characteristics of financialization cited by Hein (2011) and the sizable remuneration of savings is the main feature of Aglietta's (1999) "patrimonial capitalism". In what concerns finance at the international level, the rising power of rentiers is important for understanding 
the policies (and choices of non-intervention) that allowed financial globalization to take place and the market incentives that pushed financial innovations.

\subsection{Transformations of finance}

A second important group of financialization-related phenomena includes the changes within the financial system, as the increasing importance of markets, the evolution of banking, and the innovations of products and practices in terms of portfolio investment.

\subsubsection{The increasing importance of markets and the evolution of banking}

A main change in banks is the increasing role of markets that followed, among others, the increasing use of securities. The role of banks in credit intermediation changed with the emergence of securities, a development that is rooted in the bad solvency-ratios of U.S. banks due to developing countries debt crises at the beginning of the 1980s. In that context, securities appeared as a solution to allow banks to put risky debtors off balance-sheets and to make themselves intermediates only, passing these risks to other institutions. Debt was then fractionated into smaller pieces and constantly renewed; as a result, investors make up for longer debt maturities and banks intermediation is limited to cases of insufficient liquidity in markets (Bourguinat, 1992).

Observing the increasing role of markets, Aglietta (1999) argued that the financial system would have shifted from being "banking-based" to "market-based". A more accurate picture might however be that of a financial system that is still mainly based on banks, that also have access to markets, characterizing a marketbased banking system; for instance, banks acquire and issue equities in markets and act as fund managers (Minsky (1990); Plihon (1995)). Indeed, fund management is a current function of banks alongside commercial banking, investment banking, private wealth management, and insurance. With these new functions, banks evolved to financial institutions called "do-it-all" groups, "financial supermarket", or "fullservice" banks - and form a very concentrated industry around the globe (Pastré (2007); Plihon et al. (2006)). In these institutions, capital markets are used as a source of income in addition to the traditional functions of commercial banks (Prates and Farhi, 2015).

Risk management techniques have also gone through important changes: While banking institutions used to do private evaluations based upon the specific knowledge of each debtor, now they also use statistical data to infer probability distributions of risk characteristics (Aglietta, 2001), a practice that allowed financial institutions to "originate and distribute" their loans to other institutions, substituting the prior practice of "originating and holding" them (Brunnermeier, 2008). By doing 
so, banks have become less cautious about their lending practices as risks are passed to other agents and no longer profit from carrying the operation, but from the transactions' fees (Kregel, 2008) ${ }^{6}$.

These changes have increased risks. Aglietta (1999) stresses the features of market- vis- $a$-vis banking liquidity. In a bank, liquidity is totally and permanently held because deposits are assured and the bank has access to the ultimate liquidity, that of the central bank. Market liquidity, on the other hand, is a collective imagination of participants, not an objective reality, as it is relative to the equilibrium between the diverse expectations of buyers and sellers. In the case of doubt about the prevailing collective opinion, liquidity deteriorates abruptly, causing a major shift in prices and instability. This constant risk of losing capital might also oblige market participants to speculate on the future evolution of assets' prices, what in turn depends on the behavior of other market participants (as in Keynes' beauty contest). Speculation would thus be a necessity of the functioning of financial markets, making financial fragility inherent to its dynamics.

In the Post-Keynesian framework, this dependency on the expectation about collective opinion comes from the very fact that prices change according to the demand, which itself can change abruptly, following participants' expectations. A fundamental issue of financial asset markets is that their high volatility makes participants aware of the high risk, triggering a desire to be among the "first to move", generating herd behavior that then feeds back into volatility. This problem is intrinsic to financial markets due to (Knightian) fundamental uncertainty, that refers to situations in which "at least some essential information about future events cannot be known at the moment of decision because this information does not exist and cannot be inferred from any existing data set" (Dequech, 1999, p. 415-416), as "the future is yet to be created" (Dequech, 2000, p. 41).

In this environment, the decisions made by money managers are the main determinants of liquidity and prices. Their major impact on prices derive from the fact that they are a limited number of agents, who hold significant amounts of capital, and tend to make similar decisions (as they are guided by the same assets' ratings and tend to simulate important indices (Plihon and Ponsard (2002)). In addition, aware of the impact of money managers on prices, other investors follow them - for instance, a better country rating results in capital inflows not only from money managers who follow a rating-based rule, but also from investors that are attracted by the expectations of a price change following money managers' decisions. Finally, institutional investors' decisions are also important simply due to the presence of

(6) Lapavitsas (2009, p. 110) highlights other changes within finance, such as changes in the internal organization of financial institutions, speed of transactions, feasibility of financial engineering, links between financial markets, and pricing techniques. 
herd behavior: they have an impact on markets, and this change will be followed by trend-following investors (as described in the work of Schulmeister (2009)).

The change towards a market-based bank system has therefore brought an inherent fragility due to the power of a few institutions to determine prices and because of the volatility cycle it engenders: their decisions are based on expectations that change abruptly, and for this reason, expectations matter. The new structure is also riskier because of the financial innovations. As price changes can be of great magnitude and given the possibility of investing and being funded abroad and the risks related to the exchange-rate, the use of derivatives products ${ }^{7}$ has flourished as investors aimed to reduce their risk by choosing which type of risk to assume and to what degree (Aglietta (2001); Guttmann (2008)). These innovations have a direct impact on the dynamics of finance at the international level and will be discussed next.

\subsubsection{The changes seen within the financial system and financial innovations}

Financial innovations are crucial for understanding financialization as they favor speculation ${ }^{8}$ - an activity that better describes the current function of finance than in other phases of capitalism. In the words of Minsky, speculation changed the focus of financial markets in Money Manager Capitalism towards the "quick turn of the speculator, upon trading profits", from its earlier focus on the capital development of the economy (Minsky, 1992, p. 111) ${ }^{9}$. Similarly, Aglietta (1999) argues that finance no longer has the function of serving capital accumulation. Still, Guttmann (2008, para. 23, italics added) says that:

[Finance-led capitalism] has given priority to fictitious capital whose new conduits, such as derivatives or asset-backed securities, are several layers removed from any real economic activity of value creation. In that realm the key objective is to trade paper assets profitably for capital gains, an activity best described as speculation.

The new weight of speculation is seen in the innovations of products and practices, that are presented in the sequence. Before this, it is interesting to note that the rapid pace of these two types of financial innovations can be explained by their profit prospects (Lapavitsas, 2008) as well as by their characteristics: unlike

(7) According to Dodd (2005), the use of derivatives, in general can be traced back centuries or even to Aristotle's period. What we refer to as innovation is the broad use of derivatives of financial products.

(8) The article follows Kaldor's (1939) definition of speculation: "Speculation [...] may be defined by the purchase (or sell) of goods with a view to re-sale (re-purchase) at a later date, where the motive behind such action is the expectation of a change in the relevant prices relatively to the ruing prices and not a gain accruing to their use" (p. 1).

(9) Here Minsky is comparing the function of financial markets in different phases of capitalism in the US, Finance capitalism and Money Manager capitalism. 
industrial innovations, financial innovations are simply contractual arrangements, being easily implemented and readily copied given that they are devoid of protection by intellectual property rights, resulting in much shorter life cycles (Guttmann, 2008).

\section{Innovations of products}

The broad use of products as futures, options, forwards, or swaps reveals the current speculative function of finance. These are excellent tools of speculation due to the leveraging possibilities they offer that make risk-taking cheaper and more available (Dodd (2005); Farhi (1999); Guttmann (2008)). As reminded by Prates and Fritz (2016, p. 187):

One important characteristic of financial derivatives as a whole is their high degree of leverage, to the extent that they require only a margin requirement or the payment of a premium to be carried out. This specific feature, in turn, makes FX derivatives a privileged instrument for currency speculation and profiting from interest rate differentials.

Apart from favoring speculation, derivatives add pressure on spot markets through arbitrage, or for being an extra conduit of spot exchange-rate determination: as the pricing of forward exchange rate is given by the spot rate plus the cost of carrying the asset ${ }^{10}$ (the interest rate) any change in one of the markets translates into a change in the other. When derivatives markets are insignificant in comparison to spot markets, the influence goes from the spot to the derivatives market. But when derivatives markets gain weight, the rates in the two markets constantly influence one another (Farhi, 1999). Derivatives markets are therefore a determinant of the spot rate and can also increase their volatility given that they are more volatile and subject to changing expectations.

There are also risks related to derivatives, such as 'outflanking' laws and regulations and manipulating accounting rules (Dodd, 2005). Innovations are also pro-cyclical: as they change profit prospects and facilitate investments, but an increase in risk aversion can induce a desire to unwind debt financing (Minsky, 1990) - as is the case of the innovations that fed the boom in house prices and the Global Financial Crisis (Brunnermeier, 2008), and that fed the Asian crisis in the late 1990s (Dodd, 2005).

(10) If both the spot prices and the interest rate do not change and the forward price increases, market participants will see an opportunity for arbitrage and buy the asset on the spot and sell it on the derivatives markets. The more liquid the derivatives markets are, the more intense this connection between the three variables will be (Farhi, 1999). Note that it is a simple arbitrage operation that does not involve any expectation about future exchange rates. It is an arbitrage on the covered interest rate parity (Rossi, 2014). Fernandes (2008) argues that in the case of the Brazilian real, whose future market is much more liquid than the spot one, the causality runs from the future to the spot rate. Also see Upper and Valli (2016). 
Indeed, the consequences of speculation in terms of stability are well known. Different from Friedman's view of stabilizing speculation on FX markets, speculation led to notorious crises in EMEs and advanced economies. Risks have recently increased with the emergence of high frequency trading and dark pools ${ }^{11}$. With a combination of the two, investors can trade according to algorithms, benefiting from privileges such as greater or faster access to information in a completely opaque environment (without making their orders public). The risks associated with these two instruments include a very rapid collapse in prices (the 'Flash Crashes' ${ }^{12}$ ) and the determination of market prices at the will of few large international banks - the most notorious one being the manipulation of the Libor (Farhi and Prates, 2016).

\section{Innovations of practices}

Aside from product innovations, the high level of sophistication of finance in times of financialization is also revealed by the innovation of practices. While the former allow speculation, the latter are manifestations of it. Carry trading operations and the financialization of assets (as commodities and currencies) are two examples discussed in the following section. A specific financial innovation is the financialization of commodities and currencies, that are important examples of the creation of asset classes from other assets. Commodities' financialization refers to the observation that commodities are traded as an asset class given that i) their price dynamics follow more the logic of financial markets than that of a typical goods market (UNCTAD $(2009 ; 2015)$, and that ii) this change of dynamic was associated with an increase in the position of portfolio investors on these markets, as revealed by the sizable volumes of exchange-traded derivatives - a value 20 to 30 times larger than physical production (Unctad, 2012). The financialization of commodities begun in the early 2000s: After the collapse of equity markets in 2001 and the "widely publicized discovery of a small negative correlation between commodity returns and stock returns", commodities were promoted as an interesting asset for reducing portfolio risk (Tang; Xiong, 2010, p. 12). The use of these different commodities as a part of a common portfolio diversification strategy has however resulted in higher volatility, higher correlation between their prices and increasing sensitiveness to international market conditions (Kyle; Xiong, 2001; Unctad, 2009). The higher correlation between asset markets is explained by contagion: the need for liquidity in a market calls for withdraws in another (Aglietta, 1999), as the strategy of financial

(11) High frequency trading is a "class of electronic trading featured by high-speed connections and the use of complex algorithms" (Prates; Farhi, 2015, p. 3), while dark pools are "equity-trading systems that do not publicly display orders" (p. 14).

(12) Farhi and Prates (2016, p. 10) define Flash Crash as "a very rapid, deep, and volatile movement in security prices occurring within an extremely short time." There have also been flash rallies of prices. 
investors is determined by their "own needs" that are related to financial markets in general (Unctad, 2009, p. 23).

Another important type of financialization of assets is the financialization of currencies, the consideration of a currency as an asset class per se, with the expectation of incurring gains from the changes in their values. Currency trading is in fact a more distinguished process than trading an asset denominated in that currency, due to money's special attributes of the denominator of contractual obligations and the medium with which these are met (Kaltenbrunner, 2011). The results from the financialization of currencies are similar to that of commodities. Kaltenbrunner (2011) found that the Brazilian real became characterized by large swings in the exchange rate and by a higher vulnerability to international market conditions. Studying currencies of emerging countries, Ramos (2016) found that the use of these countries' assets in innovative strategies leads to high exchange rate volatility due to frequent extreme depreciations and a strong association with the conditions of international financial markets.

Carry trading is another innovation that has a direct impact on finance at the international level. Canonical carry trade is a non-hedged investment strategy based on borrowing in a currency of lower interest rate (the funding currency) and investing in a high-interest-paying currency (the investment or target currency) (Burnside et al., 2006; Unctad, 2007) ${ }^{13}$. It can therefore be seen as a bet that "the exchange rate will not change $[e]$ so as to offset the interest rate differential $\left[i *_{-} i\right]$ " (Galati and Melvin, 2004, p. 69) - as represented in Equation 1 where an increase of $e$ denotes a depreciation in the investment currency, $i *$ is the interest paid by the asset in the investment country and $i$ is the return paid by assets in the funding country. Derivatives carry trade, on the other hand, involves being sold in the funding currency and bought in the investment currency through currency futures and forward contracts (Gagnon and Chaboud, 2007). Derivatives carry trading is thus a form of currency financialization.

$$
i^{*}-i>e
$$

(13) The U.S. dollar, the Japanese yen, and the Swiss franc are often cited as funding currencies. The Australian dollar, the New Zealand dollar, the Brazilian real, the Hungarian forint, the Mexican peso, the South African rand, and, to a lesser extent, the Indonesian rupiah, the Indian rupee, the Philippine peso and the Turkish lyra are often cited as investment or target currencies (Galati and Melvin (2004); UNCTAD (2007); Gyntelberg and Remolona (2007); Heath et al. (2007); Ramos (2016)). The role of the U.S. dollar might have shifted from funding to target with the end of low interest rate policies in the early 2000s (Heath et al., 2007), but since then the GFC is most certainly a funding currency. See Burnside (2006) for an empirical analysis of the Japanese yen and the consequences of being a funding currency. 
Given the difficulty of finding it in the data (Heath et al., 2007) ${ }^{14}$, there is no consensus on when carry trading started. Its use can be found in the early-20th Century, however it certainly gained importance by the end of the century, when it funded the bubbles leading to the Asian crisis. Evidence of the consequences of carry trade operations in the yen can be found in the late 1990s (Burnside et al., 2006) and that economists (and international institutions, such as the BIS) begun paying more attention to carry trade. It was also by the end of the 20th Century that the definition of carry trade started centering on investments that involve two different currencies, as revealed by the use of the term currency carry trade (Rossi, 2016). In the 2000s the literature begun referring to them as "famous carry trade" and they are seen as the reason behind the surge in FX markets from 2001 to 2004 (Galati and Melvin, 2004) - when they were favored by the low interest rates of advanced economies. Regardless of when the first wave of carry trading took place, its broad use since the 1990s is an important innovation of practice.

Regarding EMEs, another relevant innovation with regards to practices is foreign portfolio investment in domestic-currency-denominated assets. The demand for EMEs' assets increased substantially from the beginning of the 2000s, but most importantly, their share in foreign investors portfolio also increased. Goldman Sachs (2010) estimated that the share of EMEs' equities in the MSCI World Index ${ }^{15}$ increased from 5\% in 2000 to $13 \%$ in 2010 and Bonizzi (2013a) shows the same pattern in the portfolios of U.K. pension funds - by 2012, emerging market equity investments achieved $19 \%$ of total equity investment, substantially increasing from $8 \%$ in 2001.

As seen in Kaldor's (1939) definition of speculation, the innovations of products and practices that accompanied financialization are strongly speculative due to their focus on exchange rate returns. In other words, these speculative innovations of products and practices allow foreign investor to profit from the exchange rate return in addition to gaining from the asset's price change. In the case of speculation through FX derivatives, derivatives carry trade or, in a broader sense, currency financialization, this is clearly the case: the result of the transaction is the variation in the exchange rate. The exchange rate return is however also a crucial part of canonical carry trading, given it is based on the expectation that the investment currency will not depreciate as to offset the interest rate differential $\left(e<i^{*}-i\right.$, in Equation 1). The increasing exposition to domestic currencies as through equity investment (Goldman Sachs, 2010; Bonizzi, 2013a; Kaltenbrunner and Paincera, 2014), is also an example of focus on exchange rate returns.

(14) Ramos (2016) suggests the use of balance-of-payment and FX-related indicators in analyzing whether there is evidence of carry trading operations involving a currency.

(15) MSCI's All Country World Index refers to global stock market activity. 


\subsection{The increasing importance of finance at the international level and its decoupling from earlier functions and logic}

While there is growing literature on the evidence of financialization in the productive economy (section 2.1) and innovations of finance have been the object of study for some time (section 2.2), not much is said about the manifestations of financialization in the international sphere. As a consequence, only quantitative aspects are analyzed in studies on the international sphere, based on the synonymous concepts of financial integration or globalization. For instance, Bibow (2009, p. 7) defines financial globalization as "the integration of national financial systems through rising cross-border financial flows and asset holdings" and Arestis et al. (2005, p. 507) define it as "the integration of financial markets of all countries of the world into one".

Financial integration is the result of the combined actions of governments and financial markets. While the first allow it to take place through policies (or nonpolicies) of deregulation and with liberalization, it is only with financial markets' consensus that a country will be integrated, as they are the ones who define which country and market will be integrated (Chesnais, 1997). Liberalization is therefore not a sufficient condition for integration (Arestis et al., 2005).

Among advanced economies, integration followed the deregulation and liberalization policies in the US and in France in the 1960s (with the interest equalization tax and the deregulation of banking lending rates, respectively) and in the UK with the repeal of foreign exchange (FX) controls in late 1970s (Goldstein; Mussa, 1993). The lack of government intervention on the rising euro-dollar market in the 1960s is also a crucial moment - though not a policy, it is a choice of nonintervention that follow the direction of the liberalization policies (Prates, 2002). Among developing countries, integration only substantially rose after the implementation of the Washington Consensus policies of domestic and international liberalization in the 1990s (Epstein; Power, 2003).

Keeping in mind that the dynamics of financialization (as the rise of rentiers and financial innovations) have an impact on financial integration, and that the use of a given innovative product or practice in a market or a country depends on financial actors' choices, the motive, dynamics and consequences of integration are not expected to be the same across countries, nor with time, requiring analyses of integration to consider its features. In other words, when only the magnitude and not the characteristics are considered, cross-country or time-series studies imply that the integration is of the same type in different countries, or that it has not changed from one period to the other, which is to deny that financial actors have different objectives with investments in different markets and that they innovate according to a change in such objectives. 
The rapid growth of financial integration is mentioned by several authors, as Chesnais (1997) who mentions the rise of ownership of foreign assets in portfolios of U.S. pension funds, from $0.7 \%$ in 1980 to $5.7 \%$ in 1993 . Also, the fact that portfolio investment grew faster than other components of international transactions (Chesnais, 1997) or faster than trade is mentioned: Baker et al. (1998, p. 10) shows that the value of funds raised on international financial markets as a percentage of world exports rose from $0.5 \%$ in 1950 to over $20 \%$ in 1996 in the member countries of the Organization for Economic Co-operation and Development (OECD). Plihon (2010) also compares financial integration with production and trade when he discusses the increasing weight of financial flows on France's balance of payment (from $28.8 \%$ in 1980 to $92.8 \%$ in 2005) and relative to its GDP (from $14 \%$ to $448 \%$ in the same period). In addition, the author compares this dynamic with that of current account transactions, that not only decreased in the balance of payments, but were also stable in terms of percentage of GDP (around 35\%).

The rapid growth of FX transactions is another expression of financialization at the international level that is highlighted by several authors. Chesnais (1997) mentions the rapid growth of FX transactions - they six-folded from 1986 to 1992 in the US, UK and Japan and Epstein (2005) observed that global FX transactions almost four-folded from 1989 to 2004 . This is also the subject of several BIS studies, that more recently also analyze the reasons behind this growth - Moore et al. (2016) study the "financialization of the renminbi", based on the fall of the share of FX spot transactions; the sophistication of FX derivatives, with FX swaps representing more than $40 \%$; and the falling participation of non-financial counterparties, that are currently responsible for only $8 \%$ of transactions involving the renminbi.

From these observations, Chesnais et al. (1996) has argued that financial integration is not the same as in other phases of capitalism, in which it was associated with assuring the financing of the international trade and of the balance of payments. For Plihon and Ponsard (2002), finance has therefore only indirect links with these functions and follows its own logic.

\section{Evidence of the logic of finance at the international level and financialization}

The mentioned observations regarding the increasing magnitude of the two expressions of finance at the international level - financial integration and FX transactions - suggest the disconnection of finance from its prior functions, but do not further elucidate its new function. These findings are also solely related to advanced economies. The empirical analyses presented in this section aims to bridge these two gaps. From the identification of the rising focus on exchange rate returns among financial innovations of products and practices, financial integration and FX transactions are analyzed with the objective of studying whether this focus could be guiding foreign investment in these economies. As it will be shown, when comparing 
EMEs and advanced economies, the disparity of FX-related figures is striking. This difference should however not be taken as an indicator of different states of financialization as they derive from the current configuration of the International Monetary and Financial System (IMFS). This is debated below, prior to a presentation of the empirical evidence.

\subsection{The different magnitude of FX turnovers and the hierarchy of the international monetary and financial system}

FX transactions involving emerging currencies have been growing fast and the total market value in 2016 was 8.4 times higher than that of 2004 due to a fast growth of derivatives contracts (that now represent $67 \%$ of EMEs' FX market). Although most of this growth was related to contracts with the Chinese renminbi, growth was significant in every EME's currency, its cross-country median having five-folded from 2004 to 2016. The increase seen among emerging currencies was higher than among advanced currencies (the latter having "only" tripled in size in these 12 years) resulting in an increase in the share of EMEs' currencies. Their participation in total FX markets is however still marginal, $10.6 \%$ - similar to that of the Japanese yen, half of that of the euro, and $20 \%$ of that of the U.S. dollar.

These major differences in the number and value of transactions involving different currencies can be only partially explained by differences in GDP or trade. The remaining difference is due to the hierarchical nature of the international monetary systems (IMS). Since the emergence of the Bretton Woods agreements, the dollar is at the center of the IMS, with the other currencies occupying a secondary position (Carneiro, 1999). The differentiation between the dollar and the other currencies depends on whether they perform the functions of money in the international context (Prates, 2002) - means of change, unit of contract denomination and reserve of value. The U.S. dollar is the only one to fully preform the three functions. Currencies from other central countries ${ }^{16}$ occupy the second place as they are also used to denominate contracts internationally (unit of account) and are in relative demand as a store of value. Currencies from peripheral countries occupy the third place, as they do not exercise any of the three functions internationally (Prates (2002); Prates (2005); Andrade and Prates (2013)). With the increasing importance of the euro as a store of value and a unit of account, it might now be seen as the second most central currency; and there is a growing hierarchy among peripheral

(16) In line with the definition used in this article, emerging market economies are developing countries, as opposed to advanced economies. In a center-periphery framework, the first are peripheral countries, as opposed to central ones. 
currencies as some of them are increasingly used at the regional level (De Conti; Prates; Plihon, 2014) ${ }^{17}$.

The high use of the U.S. dollar (it was on one side of $88 \%$ of all transactions in 2016 (BIS, 2016)) is explained by its centrality in the IMS. Because it is the central currency, and the most used as unit of account and means of payment, the U.S. dollar is often used for trade among two countries other than the United States. The centrality of the U.S. dollar also explains why data on trade concerning the U.S. economy are not useful to explain the magnitude of transactions involving the U.S. dollar - seen by the fact that its FX-to-trade ratios is much larger than that of any other currency. Indeed, these ratios for the U.S. dollar have been, on average, 2.08 times higher than the median value for advanced economies since 2004.

The hierarchical nature of the international financial system (IFS) also helps to explain the difference of the scale of FX turnover values among advanced economies. Due to IFS' asymmetries, capital flows are mostly directed to a few central countries and peripheral economies receive only marginal amounts. When looking at FX turnover of different advanced economies, we see that those with the highest absolute values and the highest values relative to GDP or trade are the Japanese yen, the New Zealand and the Australian dollars, the Swiss Franc, and the British pound, the first three being broadly known to carry trading currencies and the others known for their functions of reserve of value.

The power of these two asymmetries in explaining the magnitudes of FX markets for advanced economies' currencies is evident when we compare the relative values of FX with regards to trade with the ratio of FX to financial integration ${ }^{18}$ (the FX-to-FI ratio, that will be studied later in this section). As will be seen, trade only weakly explains FX turnover, seen by the fact that the FX-to-trade varies more across advanced economies than the FX-to-FI ratio: the standard deviation of the former in 2016 being 0.27 and that of the latter 0.07 .

In conclusion, the magnitude of FX transactions involving the U.S. dollar is explained by its use as means of payment, unit of account and reserve of value. The high use of other advanced economies' currencies is explained by their "financial use", as reserve of value or in carry trading activities. The analysis of the use of emerging currencies must be carried out against this background, and knowing that the magnitudes of FX markets are expected to be much lower given that they do not

(17) See De Conti and Prates (2014) for an analysis on the current IMS configuration based on data on the specific uses of money that are associated with each of its three functions.

(18) FX turnover represents an amount traded in a day, while financial integration (as discussed in the Introduction) is measured as the stock of foreign assets and liabilities a country holds by the end of the year. The ratio can therefore be seen as the daily amount of transactions related to a given stock of capital held abroad or owned by a foreigner institution. 
perform the functions of money in the international sphere. Given this structural difference, what is interesting for the analysis of financialization of these countries in the international context is the rate of growth of FX transactions relative to its potential determinants.

\subsection{The rising financial motive and the speculative logic of finance at the international level}

The financial integration of EMEs and FX transactions with their currencies are studied in this section with the objective of analyzing the function of finance at the international level and the extent of speculative reasons.

The analysis of the growth of FX transactions in comparison to that of trade hints to the weight of the financial motive behind FX transactions. This is carried out through an estimation of the FX-to-trade ratio (see Figures 1 and 2, that respectively present the pattern of growth of the FX-to-trade ratios from 2004 and 2016 and a comparison of the magnitudes involved).

Figure 1

FX Turnover Relative to Trade and Financial Integration: EMEs, 2004 to 2016
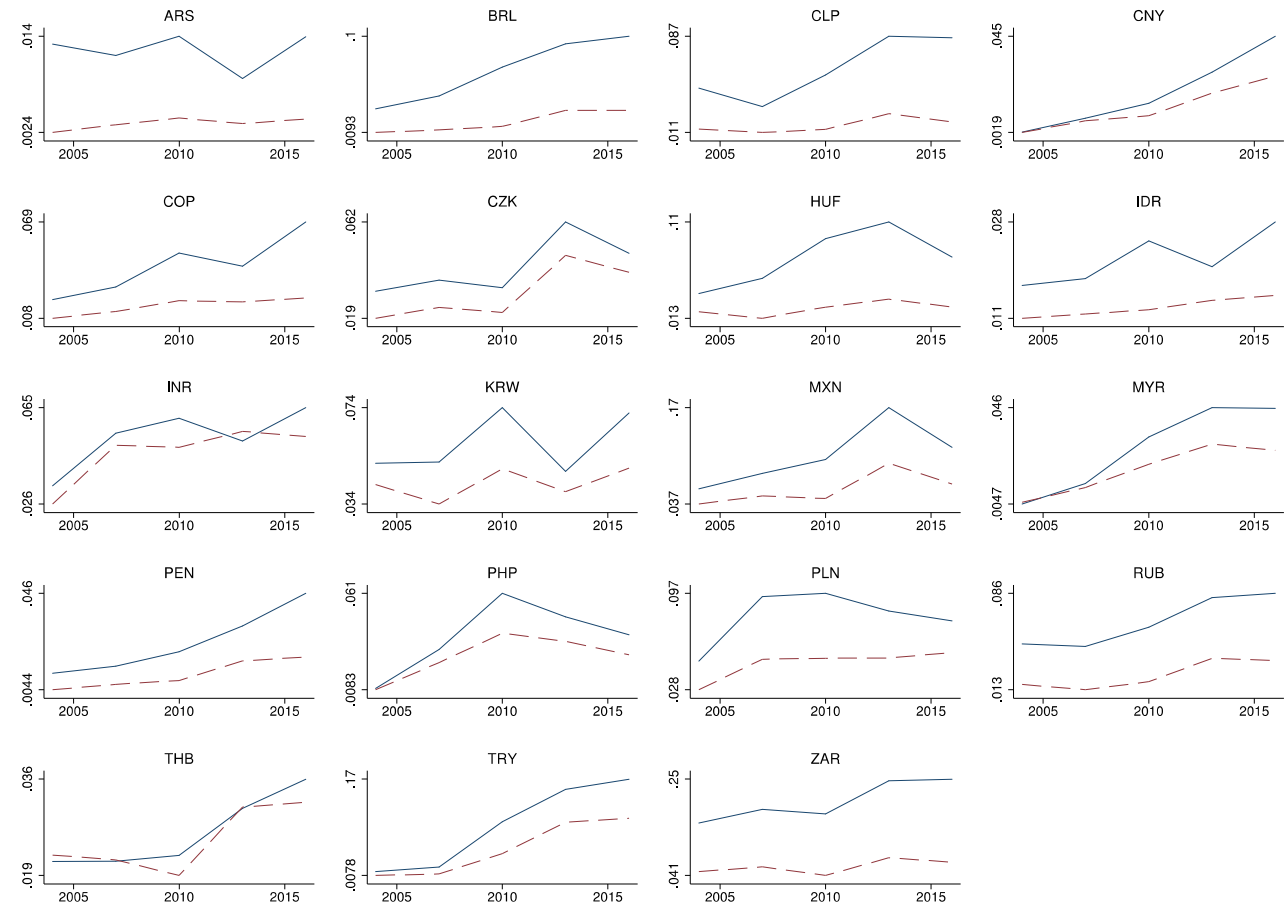

FX-to-trade is represented by the solid blue line; FX-to-FI, the dashed red line. The axis labels indicate the minimum and maximum values of the two variables in each country.

Source: Own calculations. Data source: BIS, IMF and WDI. 
In the last 12 years the ratio grew in every EME, indicating the presence of a financialization process in these countries. In other words, the fact that the growth in FX transactions was greater than what would be "needed" for trade-related operations suggests that the motive behind these transactions was financial.

Precisely speaking, the median FX-to-trade ratio among emerging currencies more than doubled between 2004 and 2016, from 0.03 to 0.07 (see Table 1). This indicator suggests financialization processes of different intensities across EMEs, the most intense being those where the ratio grew the most: Turkey $(0.16$ percentage points), South Africa (0.10 p.p.), Brazil (0.07 p.p.), Mexico (0.06 p.p.), and Colombia (0.05 p.p.; see Figure 2), but the FX-to-trade ratio has been growing relatively continuously since 2004 in most EMEs (with the exception of Argentina, Indonesia, Korea, and Poland; see Figure 1). The rapid growth of this ratio is even more telling about financialization among EMEs when viewed in light of the stability of this ratio among advanced economies' currencies (at 0.32; see Table 1). Indeed, it is only in Argentina and Korea that the growth of FX-to-trade was lower than advanced economies' median.

Figure 2

FX-to-trade Ratio among Emerging Market Economies: 2004 and 2016

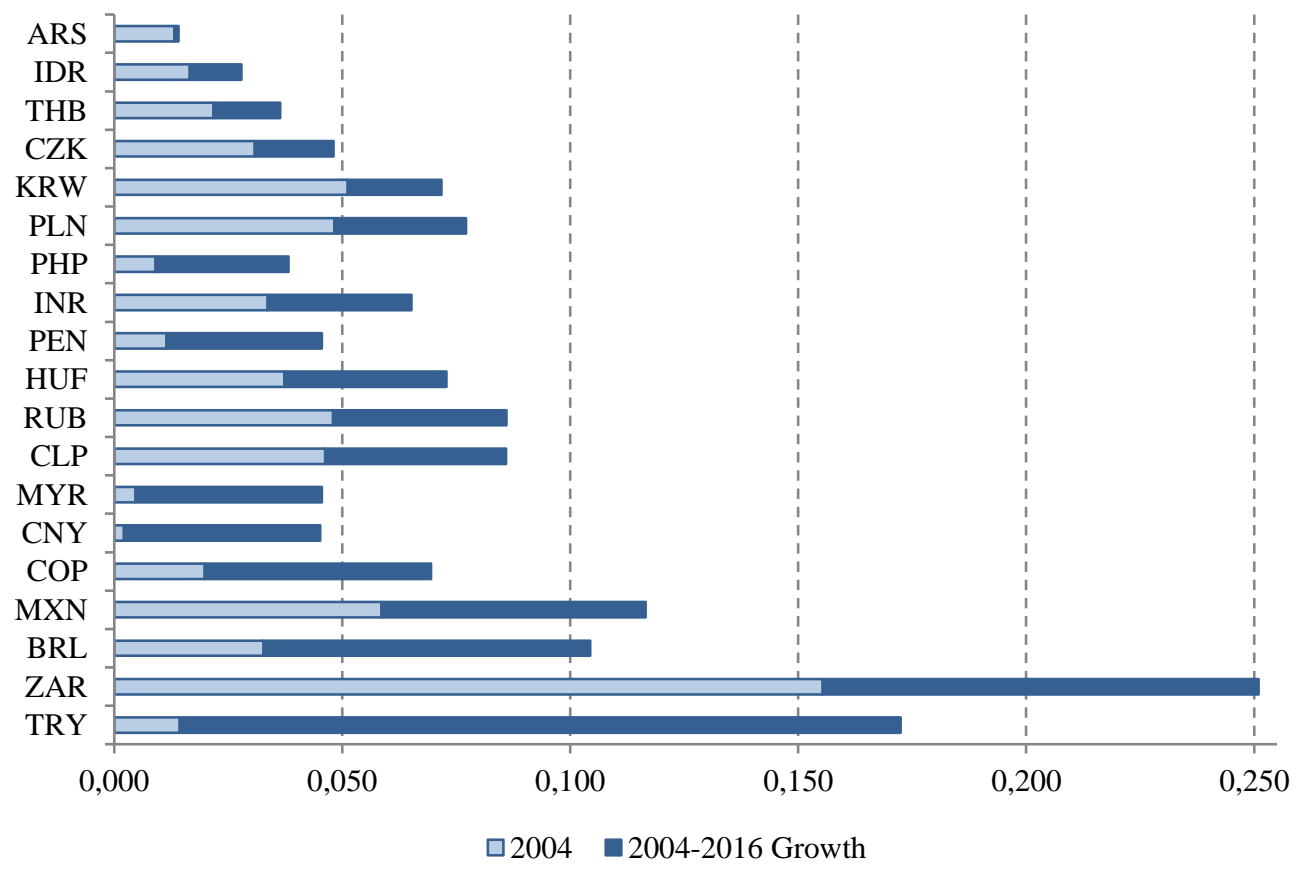

Countries by the growth of the FX-to-trade ratio from 2004 to 2016. Source: Own calculations. Data source: BIS and WDI. 
The high growth of FX-to-trade could be said to indicate a higher hedging culture as FX growth was mostly due to a rise of derivatives contracts. The analysis of the composition of FX transactions points however to the opposite direction. In several countries the share of derivatives increased in tandem with a decrease in the share of non-financial costumers, suggesting that the rise of derivatives, thus of FX, is not related to trade transactions, but undertaken by financial institutions. The growth of the FX-to-trade ratio is, in this case, an indicator of the process of financialization among EMEs: the growth in FX is not due to trade reasons, but disconnected from their needs.

The fact that trade does not explain FX transactions is also found by Upper and Valli (2016) who studied the size of FX contracts in 2016 across advanced economies' and emerging currencies and conclude that trade is insignificant, while financial variables are highly significant. A time-series approach might however be more useful than the cross-country approach taken by the authors, given the structural features of different countries as the weight of trade and the centrality in the IMFS ${ }^{19}$. Such an approach cannot however include econometric techniques due to the limited amount of surveys conducted.

Table 1

Indicators of financialization at the international level

\begin{tabular}{l|c|c|c}
\hline & & EME & Adv. \\
\hline \multirow{4}{*}{ FX-to-trade } & 2004 & 0.031 & 0.317 \\
\cline { 2 - 4 } & 2016 & 0.069 & 0.318 \\
\cline { 2 - 4 } & growth (p.p.) & 0.039 & 0.001 \\
\hline \multirow{4}{*}{ FX-to-FI } & 2004 & 0.014 & 0.032 \\
\cline { 2 - 4 } & 2016 & 0.031 & 0.039 \\
\cline { 2 - 4 } & growth (p.p.) & 0.017 & 0.007 \\
\hline \multirow{4}{*}{ Derivatives' Share } & 2004 & 0.541 & 0.721 \\
\cline { 2 - 4 } & 2016 & 0.667 & 0.673 \\
\cline { 2 - 4 } & growth (p.p.) & 0.126 & -0.048 \\
\hline \multirow{4}{*}{ Non-Financial Costumers' Share } & 2004 & 0.151 & 0.158 \\
\cline { 2 - 4 } & 2016 & 0.095 & 0.077 \\
\cline { 2 - 4 } & growth (p.p.) & -0.056 & -0.081 \\
\hline
\end{tabular}

Median values for country groups.

Source: Own calculations. Data source: WDI, BIS, and IMF.

(19) A study of financialization that takes into account the centrality of some currencies in the IMFS could be carried out by analyzing the evolution of FX transactions of a central currency, as the U.S. dollar, against that of global trade, or that of the sum of trade of the United States and of peripheral countries. 
The increasing importance of the financial motive in FX transactions is also seen from the fall of the share of non-financial institutions. BIS surveys indicate that the share of non-financial counterparties of FX transactions has been falling in several EMEs. Their participation was already low in 2004, 15\% (similar to advanced economies' 16\%), and decreased to 10\% in 2016 (among advanced currencies the share fell to a median of $8 \%)^{20}$. The process took place in the majority of EMEs, with the only exception being transactions involving the South African rand (where the share was relatively stable after two years of decreases and a hike in 2016; see Figure 4). As expected, the share of non-financial counterparties varies across EMEs. The decrease in the participation of non-financial institutions was the highest in the case of the Indian rupee, the Turkish lira, the Brazilian real, and the Taiwanese dollar. This pattern indicates a strong financialization process among these EMEs, and a similar financialization process among the currencies of EMEs and advanced economies.

Figure 3

Share of derivative contracts and non-financial counterparties: EMEs, 2004 and 2016

Share of non-financial counterparties Share of derivatives
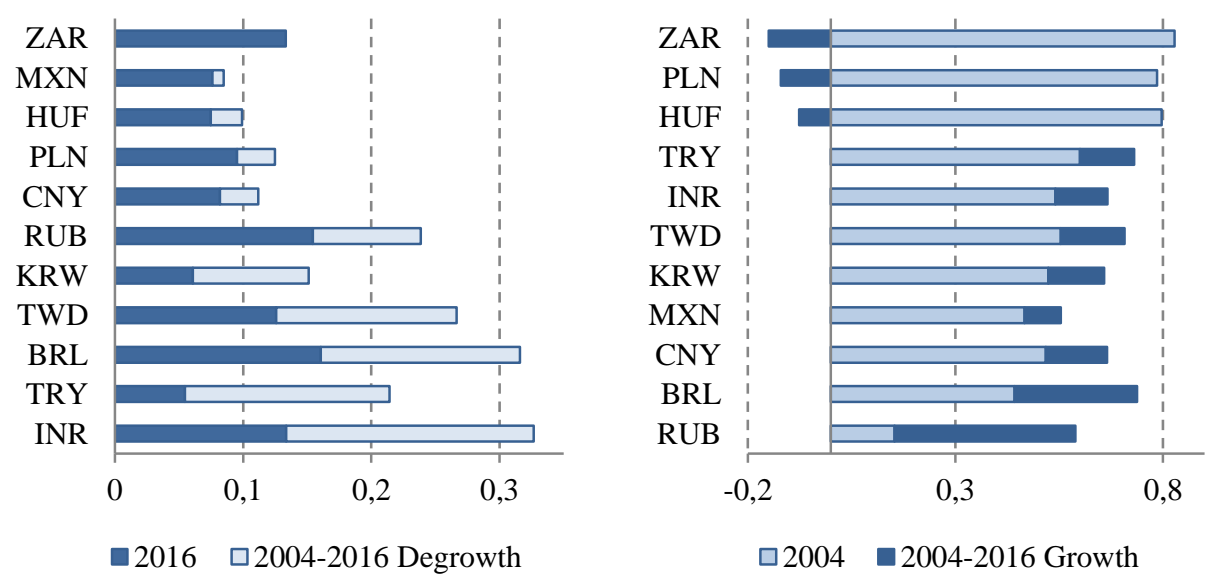

Countries by their share of derivatives in 2016.

Source: Own calculations. Data source: BIS (2016).

The fall in non-financial counterparties took place in tandem with the mentioned rise in the share of derivatives contracts (from 54\% to 67\%; while among advanced economies, spot contracts grew faster than derivatives, whose participation

(20) Details about the type of counterparty and instrument involved are not available for every EME. In the period analyzed, this data is available for 11 currencies: the Brazilian real, the Chinese yuan, the Hungarian forint, the Korean won, the Mexican peso, the Polish sloty, the Russian ruble, the Taiwanese dollar, the Turkish lyra and the South African rand. 
decreased from $72 \%$ to $67 \%$, as with EMEs). The rapid growth of derivatives was seen in several EMEs, exceptions being Hungary, Poland and South Africa, who had the highest derivatives' share in 2004. It is in the Russian ruble and the Brazilian real that the share increased considerably. The highest derivatives share are those of the Brazilian real, the Turkish lira, the Hungarian forint and the Taiwanese dollar (all among 71-74\%; see Figure 4) - among advanced economies' currencies, the Danish krone and the Swiss franc were the only ones to present higher derivatives shares than those of the four EMEs mentioned.

Figure 4

Share of derivative contracts and of non-financial costumers: EMEs, 2004 to 2016
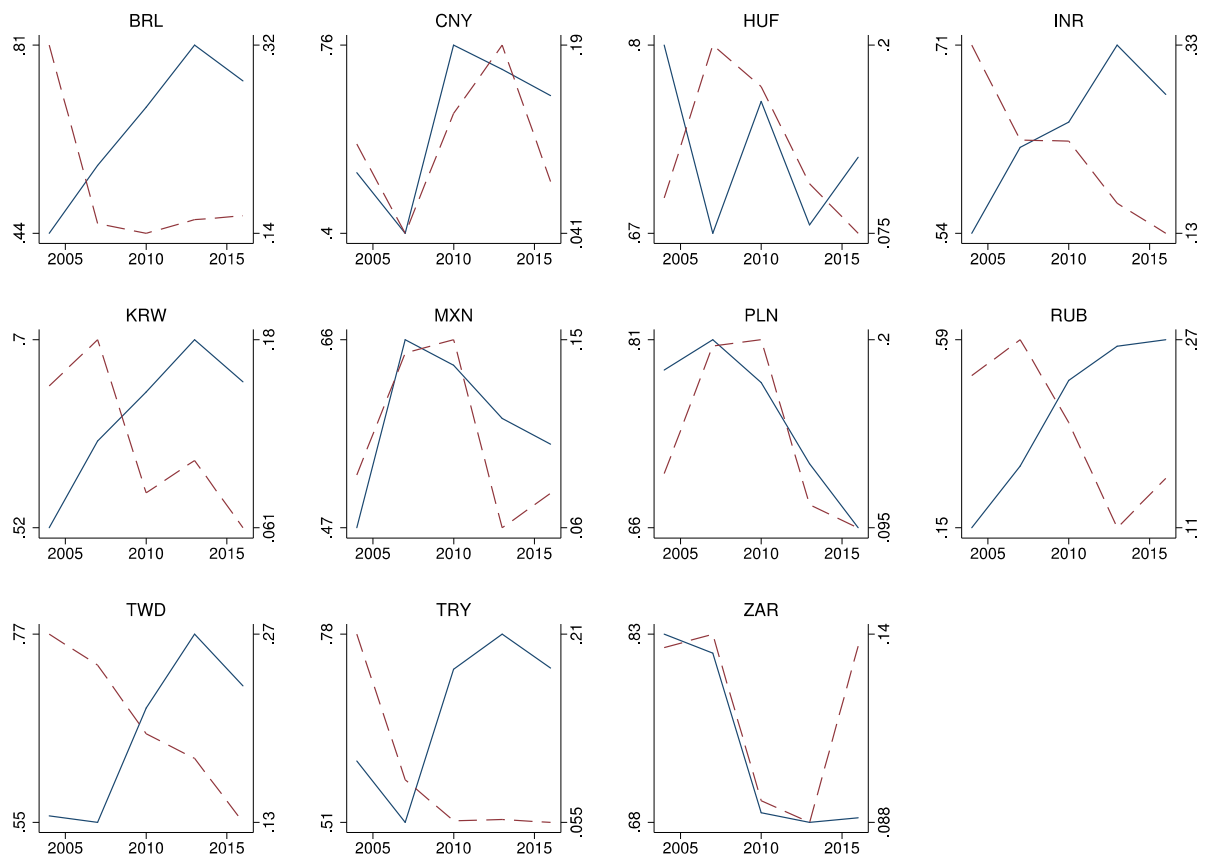

The share of derivatives contracts is represented by the solid blue line, whose minimum and maximum values are presented in the left-hand axis. The share of non-financial costumers is represented by the dashed red line, whose values are presented in the right-hand axis.

Source: Own calculations. Data source: BIS (2016).

Given the hypothesis that the growth of derivatives might be associated with a rise of the hedge culture among productive-economy related institutions, it is interesting to analyze the change in derivatives' share in light of the change of the participation of non-financial costumers. Indeed, the pattern is not the same across every EME: for instance, while in the case of transactions involving the Brazilian real the share of derivatives increased in tandem with the decrease of the share of non-financial institutions, in the case of the Chinese yuan the participation of non- 
financial institutions recently decreased sharply, but after increasing for two surveys in a row; in the case of the Mexican peso, the share of derivatives has been decreasing in the three last surveys and the share of non-financial institutions rose in three of the four surveys. A precise estimation of the relationship between these two variables in the different countries is hindered by the small number of observations, but the graphical analyses indicate that there are different types of relationship: for some emerging currencies the rise of derivatives is associated with the rise of financial counterparties and for other currencies, it is the opposite. Looking at these two characteristics of FX markets, the markets who faced significant increases of derivatives' share and significant decreases in the participation of non-financial institutions are the Indian rupee (the participation of non-financial counterparties decreased 0.19 p.p. and the derivatives' share increased 0.13 p.p.), the Brazilian real (-0.16 p.p. and 0.3 p.p.), the Turkish lira (-0.16 p.p. and 0.14 p.p.), the Taiwanese dollar (-0.14 p.p. and 0.15 p.p.), and the Russian ruble (-0.08 p.p. and 0.44 p.p.). These developments point to a more intense financialization process in these five currencies'.

The developments of a faster increase in FX transactions when compared to trade and falling share of non-financial institutions in FX markets indicate the growing importance of the financial motive behind finance at the international level (as suggested by Chesnais et al. (1996), Plihon and Ponsard (2002), Plihon (2003) and Epstein (2005) and discussed in section 2.2). Finance, at the international level, could therefore be associated with what Aglietta (1998) called, in French, a "patrimonial" logic, one focused on wealth accumulation through capital gains. The analysis of the composition of FX transactions, on the other hand, further elucidates the logic of finance. The rise of FX derivatives is in line with the innovations of products (as FX derivatives) and practices (as derivatives carry trading) that focus on exchange rate returns, which, in light of Kaldor's definition, is a different level of speculation: it is a focus on capital gains not only in terms of the assets bought, but also of the exchange rate returns. Given the leverage possibilities offered by derivatives, in comparison to alternatives based on spot transactions as buying and selling an asset, these products are an appealing alternative and their use is growing. Canonical carry trading and investment in local-currency assets are however still important forms of profiting from exchange rate fluctuations, and innovations as technical and fast trading increase the attractiveness of these spot-options.

In order to study this hypothesis of a greater focus on exchange rate returns also through spot transactions, the growth of FX transactions is analyzed in comparison to the changes in the level of financial integration through the FX-to-FI ratio. As both FX transactions and financial integration grew in every EME, a rise of the FX-to-FI ratio means that the former grew faster than the latter. A change in this 
ratio would therefore mean that for the same stock of financial integration a higher amount of FX transactions has taken place.

The FX-to-FI ratio grew steadily among EMEs, and the median ratio doubled from 2004 to 2016. Among advanced economies, on the other hand, the increase was small (see Figure 5 and Table 1). The faster rise of FX than that of financial integration helps explain the changing characteristic of financial integration. Its motive in this phase of capitalism is the accumulation of wealth, and the rising FX-to-FI ratio suggests that short-termism seen in the developments that characterize the financialization of the productive economy (debated in section 2.2) is also evident in the international sphere, as it suggests that investors stay shorter periods in a country, buying and selling the currency more frequently (increasing the value of FX transactions, but not the end-of-the-year integration). In other words, the rise of the FX-to-FI ratio suggest an integration increasingly marked by the discussed innovations of products and practices, and this was more marked among EMEs than advanced economies.

Figure 5

FX-to-FI ratio among emerging market economies: 2004 and 2016

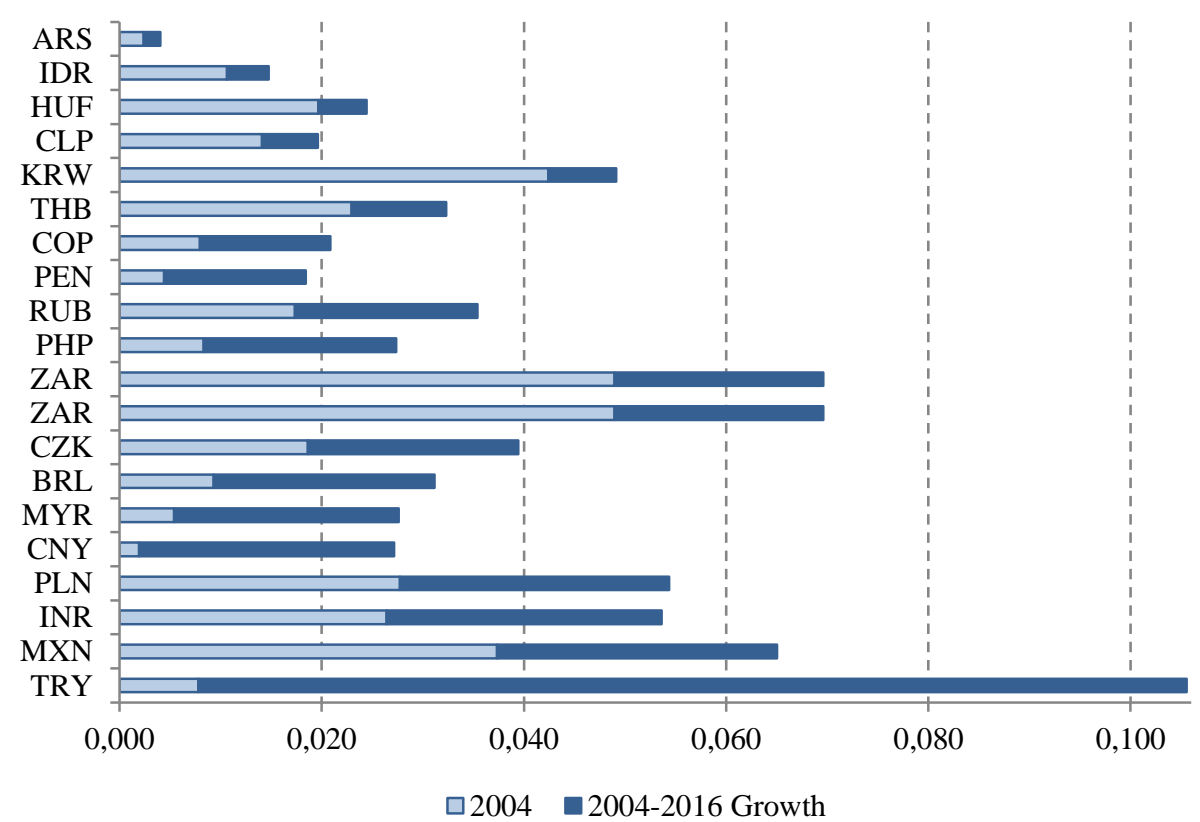

Countries are ordered by the growth of the FX-to-FI ratio from 2004 to 2016.

Source: Own calculations. Data source: BIS and IMF.

In which EMEs were these innovations most present? In some EMEs where the FX-to-FI increased the most non-financial counterparties did not fall, as occurred 
in the other EMEs, which might indicate that the FX-to-FI ratio rose due to an increase in derivatives associated with trade. These are Mexico, Poland and China (see Figures 4 and 5). Excluding these, the countries who faced the highest increase in the FX-to-FI ratio with a decrease in the share of non-financial counterparties and a rise of derivatives' share are Turkey, India and Brazil ${ }^{21}$.

Similar to the FX-to-trade ratio, the FX-to-FI values for advanced economies are much higher than those of EMEs, due to the asymmetries of the IMFS. There is however a main difference from the FX-to-FI ratio to the FX-to-trade: the values of the former differ less between EMEs and advanced economies. In 2016 advanced economies' median FX-to-FI ratio was only 1.3 times higher than that of EMEs, while these countries' FX-to-trade ratio was 4.6 times higher than the one of EMEs (see Table 1). Indeed, eight EMEs present FX-to-FI ratios that are higher than advanced economies' median (see in Figure 5). This higher similarity of the FX-toFI ratios is also seen inside country groups. The standard deviation of EMEs' FXto-FI ratio in 2016 is half of those of FX-to-trade. The same is true for advanced economies' figures, but the standard deviation related to the FX-to-FI being an even smaller share of those of FX-to-trade. This smaller variance between the two country groups and inside of them suggest that financial integration is a better indicator of the motives of FX transactions than trade, that is very loosely associated with FX transactions. This being another indicator of financialization in both EMEs and advanced economies.

\section{Conclusions}

The article groups together the broad developments associated with financialization into three: i) the changing relationship between finance and other economic sectors, ii) the changes within the financial system, including the major innovations of products and practices, and iii) the increasing magnitude of finance at the international level with the decoupling from its earlier functions and logic.

From this differentiation, financialization at the international level can be defined as the increasing magnitude of finance in the international sphere, where the prior function of financing trade and production are substituted by the strengthened speculative motive. Among EMEs, it manifests in a focus on exchange rate returns through innovative products and practices. The empirical analyses conducted with the objective of studying whether financialization at the international level could be found among EMEs conclude for the rise of the financial motive and a change of focus in the two manifestations of finance, integration and FX transactions, in some EMEs. The rise in the financial motive was seen by the faster growth of FX

(21) Malaysia saw a rise of the FX-to-FI ratio, but there are no details on the composition of its FX markets according to the type of institution. 
transactions when compared to trade, the fall of non-financial institutions, and the smaller variance of the FX-to-FI ratio compared to the FX-to-trade. The change in the focus of finance was suggested by the rise of the FX-to-FI ratio and the rising share of derivatives contracts. The two sets of evidence are analyzed in light of other changes among FX contracts, as the combined analysis of the pattern of the shares of non-financial institutions and derivatives contracts - a fall in the former together with a rise in the latter being an indication that the growth of FX contracts took place due to financial rather than trade reasons.

To conclude, the process of financialization at the international level is found in most EMEs and as a stronger process than among advanced economies as trade motives become less important and finance, at the international level, turns more intensely to the function of wealth accumulation. In addition, financialization might have different features in some EMEs. The financial motive in some EME countries presents a strengthened speculative logic, focused on gaining from exchange rate changes, in addition to assets' price changes, as seen from the analysis of the innovations of products and practices and from the empirical analyses. The combination of financialization with strengthened speculation is especially relevant for Brazil, India, Russia, Taiwan, Turkey, and South Africa.

These processes have important theoretical implications. First, it calls attention to the need to study financial integration through its qualitative aspects, or considering evidence from the currencies' FX market along with data on integration. Such analyses better indicate the extend of the speculative focus of foreign investment, which is crucial for assessing its vulnerabilities. Qualitative analyses of financial integration are in line with the observation that this is part of a broader process of financialization, that includes innovations of products and practices and the rise of money managers.

Secondly, the understanding of how finance at the international level affects EMEs has implications on exchange rate determination. Integration is led by a few money managers who have assets and liabilities across the globe - liabilities in advanced economies and assets in advanced and EMEs. This configuration leads to the emergence of a network linking these countries through these institutions' balance-sheets. A change in integration will therefore not only be related to conditions of the market in question, but to money managers' own needs, which, in turn, can be associated with conditions in any other market in the same network, funding or portfolio allocation markets. Given the asymmetry of the IFS and the small magnitude of EMEs' markets in comparison with money managers' assets (as in Haldane's (2011) Big-fish-small-compound metaphor), the change in their attitudes will however have an impact on EMEs', but not necessarily on advanced economies' markets. As these impacts are not limited to the countries' assets markets, 
but also impact its currency price, the characteristics of financial integration is therefore a key feature for understanding exchange rates.

\section{References}

AGLIETTA, M. Le capitalisme de demain. Fondation Saint-Simon, 1998.

AGLIETTA, M. La globalisation financière. L'économie mondiale. Paris: Éditions la Découverte, 1999. p. 52-67, 1999. (Collection Repères).

AGLIETTA, M.; BRETON, R. Financial systems, corporate control and capital accumulation. Economy and Society, Campinas, v. 30, n. 4, p. 433-466, 2001.

AMABLE, B. Les cinq capitalismes. Diversité des systèmes économiques et sociaux dans la mondialisation. Seuil: Collection Economie Humaine, 2005.

ANDRADE, R. P.; PRATES, D. M. Exchange rate dynamics in a peripheral monetary economy: A Keynesian perspective. Journal of Post-Keynesian Economics, v. 35, n. 3, p. 399-416, 2013.

ARESTIS, P.; BASU, S.; MALLICK, S. Financial globalization: the need for a single currency and a global central bank. Journal of Post-Keynesian Economics, v. 27, n. 3, p. 507-531, 2005.

BAKER, D.; EPSTEIN, G.; POLLIN, R. Globalization and progressive economic policy. Cambridge University Press, 1998.

BIBOW, J. The international monetary (non-)order and the "global capital flows paradox". In: FINANCE-led capitalism? Macroeconomic effects of changes in the financial sector. Marburg: Metropolis Verlag, 2009. p. 219-248.

BIS. Triennial central bank survey: Foreign exchange turnover in April 2016. Basiléia, Suiça: BIS. Monetary and Economic Department, 2016.

BONIZZI, B. Capital flows to emerging markets: institutional investors and the post-crisis environment. Paper prepared for 17th FMM Conference of the Research Network Macroeconomics and Macroeconomic Policies, Berlin, 2013a.

BONIZZI, B. Financialization in developing and emerging countries: a survey. International Journal of Political Economy, v. 42, n. 4, p. 83-107, 2013b.

BOURGUINAT, H. Finance internationale. Paris: Presses Universitaires de France (PUF), 1992.

BOYER, R. Is a finance-led growth regime a viable alternative to fordism? a preliminary analysis. Economy \& Society, v. 29, n. 1, p. 111-145, 2000.

BOYER, R. Théorie de la régulation. 1. Les fondamentaux. Paris: La Découverte, 2004. 
BRUNNERMEIER, M. K. Deciphering the liquidity and credit crunch 2007-08. Cambridge, MA: National Bureau of Economic Research, 2008. (NBER Working Paper, n. 14612).

BRUNO, M.; DIAWARA, H.; ARAUJO, E.; REIS, A. C.; RUBENS, M. Financeled growth regime no Brasil: estatuto teórico, evidências empíricas e consequências macroeconômicas. Revista de Economia Política, v. 31, n. 5, 2011.

BURNSIDE, C.; EICHENBAUM, M.; KLESHCHELSKI, I.; REBELO, S. The returns to currency speculation. Cambridge, MA: National Bureau of Economic Research, 2006. (NBER Working Paper, n. 14473).

CARNEIRO, R. (). Globalização financeira e inserção periférica. Economia $e$ Sociedade, Campinas, n. 13, p. 57-92, 1999.

CHAVAnCE, B. et al. L'économie institutionnelle. Paris: La Découverte, 2007.

CHESNAIS, F. La mondialisation du capital. Paris: Syros, 1997.

CHESNAIS, F. La théorie du régime d'accumulation financiarisé: contenu, portée et interrogations. Article présenté au Forum de la Régulation, p. 11-12, 2001.

CHESNAIS, F.; DE BRUNHOFF, S.; PLIHON, D. La mondialisation financière: genèse, coût et enjeux. Paris: Syros, 1996.

DE CONTI, B. M.; PRATES, D. M. The international monetary system hierarchy: determinants and current configuration. In: FMM 18th Conference: "Inequality and the Future of Capitalism". 2014.

DE CONTI, B. M.; PRATES, D. M.; PLIHON, D. A hierarquia monetária e suas implicações para as taxas de câmbio e de juros e a política econômica dos países periféricos. Economia e Sociedade, Campinas, v. 23, n. 2, p. 341-372, 2014.

DEQUECH, D. Expectations and confidence under uncertainty. Journal of Post Keynesian Economics, v. 21, n. 3, p. 415-430, 1999.

DEQUECH, D. Fundamental uncertainty and ambiguity. Eastern Economic Journal, v. 26, n. 1, p. 41-60, 2000.

DO NASCIMENTO, P. F.; MACEDO E SILVA, A. C. Financeirização e crescimento: alguns experimentos stock-flow consistent. In: Paper presented the 42nd ANPEC Meeting, number 85. Brazilian Association of Graduate Programs in Economics (ANPEC), 2016.

DODD, R. Derivatives markets: sources of vulnerability in US financial markets. In: EPSTEIN, G. (Ed.). Financialization and the world economy. Massachusetts: Edward Elgar Publishing, 2005. p. 149-180. 
EPSTEIN, G. Financialization and the world economy. Massachusetts: Edward Elgar Publishing, 2005.

EPSTEIN, G.; POWER, D. Rentier incomes and financial crises: an empirical examination of trends and cycles in some OECD countries. Canadian Journal of Development Studies, v. 24, n. 2, p. 229-248, 2003.

FARHI, M. (). Derivativos financeiros: hedge, especulação e arbitragem. Economia e Sociedade, n. 13, p. 93-114, dez. 1999.

FERNANDES, A. V. Microestrutura do mercado cambial brasileiro. Thesis (Master)-PUC, Rio de Janeiro, 2008.

GAGNON, J.; CHABOUD, A. What can the data tell us about carry trades in Japanese yen? FRB International Finance, 2007. (Discussion Paper, n. 899).

GALATI, G.; MELVIN, M. Why has FX trading surged? explaining the 2004 triennial survey. BIS Quarterly Review, 2004.

GOLDMAN SACHS. EM equity in two decades: a changing landscape. 2010. (Global economics paper, n. 204). Disponível em: http://www.contributors.ro/wpcontent/uploads/2010/11/0809_Global_Econ_Paper_No_204_Final2.pdf.

GOLDSTEIN, M.; MUSSA, M. The integration of world capital markets. In: CHANGING capital markets: implications for monetary policy. Wyoming: Jackson Hole, 1993.

GUTTMANN, R. A primer on finance-led capitalism and its crisis. Revue de la Régulation, v. 3, n. 4, p. 1-19, 2008.

GYNTELBERG, J.; REMOLONA, E. M. Risk in carry trades: a look at target currencies in Asia and the Pacific. BIS Quarterly Review, 2007.

HALDANE, A. The big fish small pond problem. In Institute for New Economic Thinking Annual Conference, volume 9, Bretton Woods, New Hampshire. 2011

HEATH, A., Galati, G., and McGuire, P. (2007). Evidence of carry trade activity. BIS Quarterly Review.

HEIN, E. Distribution, financialisation and the financial and economic crisis: implications for post-crisis economic policies. Berlin: Institute for International Political Economy, 2011. (Working Paper, n. 9).

KALDOR, N. Speculation and economic stability. The Review of Economic Studies, v. 7, n. 1, p. 1-27, 1939.

KALTENBRUNNER, A. Currency internationalisation and exchange rate dynamics in emerging markets: a post Keynesian analysis of Brazil. Thesis (PhD) SOAS, University of London, London, 2011. 
KALTENBRUNNER, A.; PAINCEIRA, J. P. Developing countries' changing nature of financial integration and new forms of external vulnerability: the Brazilian experience. Cambridge Journal of Economics, v. 39, n. 5, p. 1281-1306, 2014.

KREGEL, J. Using Minsky's cushions of safety to analyze the crisis in the us subprime mortgage market. International Journal of Political Economy, v. 37, n. 1, p. 3-23, 2008.

KRIPPNER, G. R. The financialization of the American economy. Socio-Economic Review, v. 3, n. 2, p. 173-208, 2005.

KYLE, A. S.; XIONG, W. Contagion as a wealth effect. The Journal of Finance, v. 56, n. 4, p. 1401-1440, 2001.

LAPAVITSAS, C. Financialisation, or the search for profits in the sphere of circulation. Ekonomiaz, v. 72, n. 3, p. 98-119, 2009.

LAPAVITSAS, C.; DOS SANTOS, P. L. Globalization and contemporary banking: on the impact of new technology. Contributions to Political Economy, v. 27, n. 1, p. 31-56, 2008.

LAZONICK, W.; O’SULLIVAN, M. Maximizing shareholder value: a new ideology for corporate governance. Economy and Society, v. 29, n. 1, p.13-35, 2000.

MINSKY, H. P. Schumpeter: finance and evolution. Prepared for a Conference: "Evolution of Technology and Market Structure in an International Contex, 1990. p. 51-74.

MINSKY, H. P. The financial instability hypothesis. Annandale-on-Hudson, New York: The Levy Economics Institute, 1992. (Hyman P. Minsky Archive Papers, n. 74).

MINSKY, H. P. [1986]. Stabilizing an unstable economy. New York: McGraw Hill Professional, 2008.

MOORE, M.; SCHRIMPF, A.; SUSHKO, V. Downsized FX markets: causes and implications. BIS Quarterly Review, 2016.

ORHANGAZI, O. Financialisation and capital accumulation in the non-financial corporate sector: a theoretical and empirical investigation on the US economy: 19732003. Cambridge Journal of Economics, v. 32. n. 6, p. 863-886, 2008.

PALLEY, T. Financialization: what it is and why it matters. Annandale-on-Hudson, New York: The Levy Economics Institute, 2007. (Working Paper, n. 525).

PASTRÉ, O. The new banking economics. Massachusetts: Edward Elgar, 2007. 
PAULANI, L. M. A crise do regime de acumulação com dominância da valorização financeira e a situação do Brasil. Estudos Avançados, São Paulo, v. 23, n. 66, p. 25$39,2009$.

PLIHON, D. Liquidité et investissement: une lecture Keynesienne des mutations financierés recentes et de leurs consequences. Economies et Societes, v. 29, n. 11, p. 57-91, 1995.

PLIHON, D. Les taux de change. Paris: La Decouverte, 2010.

PLIHON, D. [2003]. Le nouveau capitalisme. $3^{\text {rd }}$ ed. Paris: La Decouverte, 2010.

PLIHON, D.; COUPPEY-SOUBEYRAN, J.; SAÏDANE, D. Les banques: acteurs de la globalization financière. Paris: La Documentation Française, 2006.

PLIHON, D.; PONSSARD, J. P. La monté en puissance des fonds d'investissement: quells enjeux pour les entreprises? Paris: La Documentation Française, 2002

PRATES, D. M. Crises financeiras dos países 'emergentes': uma interpretação heterodoxa. Thesis (PhD)-Unicamp, 2002.

PRATES, D. M. As assimetrias do sistema monetário e financeiro internacional. Revista de Economia Contemporânea, v. 9, n. 2, p. 263-288, 2005.

PRATES, D. M. O regime de câmbio flutuante no Brasil: 1999-2012: Especificidades e dilemas. Brasília: Instituto de Pesquisa Econômica Aplicada, 2015.

PRATES, D. M.; FARHI, M. The shadow banking system and the new phase of the money manager capitalism. Journal of Post Keynesian Economics, v. 37. n. 4, p. 568-589, 2015.

PRATES, D. M.; FARHI, M. Playing it again: new financial innovations and renewed financial fragility. Manuscript submitted for publication, 2016.

PRATES, D. M.; FRITZ, B. Beyond capital controls: regulation of foreign currency derivatives markets in the Republic of Korea and Brazil after the Global Financial Crisis. CEPAL Review, n. 118, p. 183-201, 2016.

RAMOS, R. A. Financialization and its implications on the determination of exchange rates of emerging market economies. Thesis (PhD)-Universidade Estadual de Campinas (Unicamp) \& Université Paris 13, Sorbonne, Paris, 2016.

REYES, L.; MAZIER, J. Financialized growth regime: lessons from stock flow consistent models. Paris: Centre d'Economie de l'Université de Paris Nord, 2014. (CEPN Working Paper, n. 16).

ROSSI, P. L. Institutionality of the foreign exchange market and exchange rate policy in Brazil. Economia e Sociedade, Campinas, v. 23. n. 3, p. 645-667, 2014. 
ROSSI, P. L. Taxa de câmbio e política cambial no Brasil: teoria, instucionalidade, papel da arbitragem e da especulação. São Paulo: FGV Editora, 2016.

SCHULMEISTER, S. On the manic-depressive fluctuations of speculative prices. In: HEIN, E.; NIECHOJ, T.; SPAHN, P.; TRUGER, A. (Ed.). Finance-led capitalism. $2^{\text {nd }}$ ed. Marburg: Metropolis-Verlag, 2009. p. 309-335.

Stockhammer, E. Financialisation and the slowdown of accumulation. Cambridge Journal of Economics, v. 28. n. 5, p. 719-741, 2004.

TANG, K.; XIONG, W. Index investment and financialization of commodities. Cambridge, MA: National Bureau of Economic Research, 2010. (NBER Working Paper, n. 6).

UNCTAD. Trade and Development Report. Genebra, Suiça: United Nations Conference on Trade and Development, 2007.

UNCTAD. Trade and Development Report. Genebra, Suiça: United Nations Conference on Trade and Development, 2009.

UNCTAD. Don't blame the physical markets: financialization is the root cause of oil and commodity price volatility. Genebra, Suiça: United Nations Conference on Trade and Development, 2012. (Policy Brief, n. 25).

UNCTAD. Trade and Development Report. Genebra, Suiça: United Nations Conference on Trade and Development, 2015.

UPPER, C.; VALLI, M. Emerging derivatives markets? BIS Quarterly Review, 2016.

WORLD BANK. World Development Indicators 2016. Washington: World Bank Publications, 2016. Accessed on Feb. 2017. 